\title{
LEVELS OF CARCINOEMBRYONIC ANTIGEN AND CA 19-9 IN THE SERA AND PERITONEAL WASHING OF PATIENTS UNDERGOING SURGICAL TREATMENT FOR GASTRIC CARCINOMA
}

\author{
René CREPALDI-FILHO, Rogério Tadeu PALMA, \\ Marcelo Franchini GIUSTI, Marina de Assis Galvão BUENO, \\ Paulo Sérgio Lucas da SILVA and Jaques WAISBERG
}

\begin{abstract}
Background - Early peritoneal recurrence of gastric carcinoma following curative resection remains a great challenge in the treatment and prevention of this disease. Aim - To analyze the relationship between levels of tumor markers, carcinoembryonic antigen (CEA) and CA 19-9 in the sera and peritoneal washing, and anatomopathological aspects of the gastric carcinoma. Methods - Of the 46 patients in the study, 29 (63.0\%) were males and 17 (37.0\%) females. Mean age was $63.6 \pm 11.7$ years (31 to 91 years). Peripheral venous blood samples were collected from the upper limb vein from both patient groups after anesthetic induction, in order to determine serum levels of CEA and CA 19-9. After the end of the procedure, $50 \mathrm{~mL}$ of physiologic solution was introduced into the bottom of the Douglas sack and a portion aspirated to determine CEA and CA 19-9 levels in the peritoneal washing. Levels of CEA and CA 19-9 in the sera and peritoneal washing were compared to the following variables: lesion diameter $\leq 4 \mathrm{~cm}$ or $>4 \mathrm{~cm}$, lymph node involvement, angiolymphatic invasion, depth of invasion into gastric wall, and initial or late stage. Results - Sera CEA levels were significantly higher in patients with lesions $>5$ $\mathrm{cm}$. CEA levels in the sera and peritoneal washing were significantly greater in patients with signet ring cell gastric carcinoma. In addition, levels of CEA in peripheral blood and peritoneal washing showed significant association with the degree of carcinoma penetration into the gastric wall, while sera CEA was significantly higher in patients at more advanced stages. There was no significant difference between sera and peritoneal CEA values regarding grade of differentiation. Patients with gastric lesions measuring $>5 \mathrm{~cm}$ and more differentiated lesions had significantly higher sera CA 19-9 values. In patients with lymph nodes invasion by gastric carcinoma, CA 19-9 levels in peritoneal washing were significantly higher than in peripheral blood. Levels of CA 19-9 in peritoneal washing were significantly greater at advanced stages than the initial stage of the gastric carcinoma. Conclusions - Elevated levels of CA 19-9 in peritoneal washing were significantly associated with more advance stages of gastric carcinoma and was more reliable predictive factor for staging than sera CA 19-9 levels. CEA levels in the sera more accurately reflected neoplasia stage than levels in peritoneal washing.

HEADINGS - Carcinoembryonic antigen. CA-19-9 antigen. Peritoneal lavage. Stomach neoplasms. Carcinoma.
\end{abstract}

\section{INTRODUCTION}

Diagnosis of gastric carcinoma recurrence performed using traditional protocols for post-operative follow-up generally detect the disease at too later stage, a situation in which the majority of patients have no opportunity to undergo any potentially curative treatment $t^{(6,14,15,23)}$. In this scenario, the prognostic of patients with recurrent carcinoma is grim, where survival tends not to exceed 1 year $^{(14,15,19)}$.
Peritoneal cytological washing is the gold standard for determining peritoneal spread of gastric carcinoma, yet its sensitivity is relatively low, lying in the $14 \%$ to $21 \%$ range for gastric carcinoma with serosal invasion ${ }^{(1,}$ 3). One of the most extensively studied tumor markers is the carcinoembryonic antigen (CEA). Described in 1965 by GOLD and FREEDMAN ${ }^{(5)}$, CEA is routinely used as a serum marker for gastrointestinal carcinoma, particularly of the colorectal type. CEA is a glycoprotein from the superfamily of immunoglobulins whose function is to

Department of Surgery, "Hospital do Servidor Público Estadual", São Paulo, SP, Brazil.

Correspondence: Dr. Jaques Waisberg - Rua das Figueiras, 550 - apt.134 - Bairro Jardim - 09080-300 - Santo André, SP, Brazil. E-mail: jaqueswaisberg@uol.com.br 
promote cellular binding. CEA is constantly secreted by normal cells from the epithelium in the digestive tract into the intestinal lumina, and is found in both normal as well as neoplasic cells in the gastric mucous of patients with gastric cancer ${ }^{(13,20,25)}$.

CA 19-9 is a high-molecular weight mucin, defined by monoclonal antibody reacting with repetitive carbohydrate epitope of the heterogeneous family of mucins ${ }^{(7,12)}$, with a carbohydrate structure (sialylated-lacto-N-fucopentose II) whose antigenic determinant is a sialized substance from the Lewis blood group ${ }^{(12,21)}$. Elevated plasmatic levels of CA 19-9 have been found in patients with pancreatic and biliar carcinoma, as well as in patients with colorectal, gastric and hepatic neoplasias ${ }^{(7,8,16)}$.

Tumoral markers may prove valuable for the decision on indication of adjuvant therapies, particularly following curative resection for advanced carcinoma ${ }^{(4,11)}$.

The aim of this study was to ascertain the relationship between levels of the CEA and CA 19-9 tumor markers in blood and peritoneal washing, to some anatomopathological aspects of the gastric carcinoma.

\section{METHODS}

Forty-six consecutive patients who had undergone gastric carcinoma surgical treatment between July 2003 and December 2006 were analyzed. Inclusion criteria were the presence of gastric carcinoma confirmed by histopathological study of the lesion extirpated with curative or palliative intention. Exclusion criteria were carcinomas located in the cardia region, and within $3 \mathrm{~cm}$ above or below this site, and clinical or laboratorial manifestation of hepatic or pancreatic disease. The Ethics Committee of the institution approved this study.

Of the 46 patients included in the study, $29(63.0 \%)$ were females and 17 (37\%) were males, giving a male/female ratio of 1.7:1. Concerning race, 37 (80.4\%) were Caucasian, 8 (17.4\%) were African-American and $1(2.2 \%)$ oriental. Mean age was $63.6 \pm 11.7$ years ( 31 to 91 years).

Those patients with resectable lesions located in the antropyloric region were submitted to D2 standard subtotal curative gastrectomy. Patients with resectable lesions in the medium and proximal third of the stomach were submitted to D2 standard total curative gastrectomy. Patients presenting penetration of the lesion into the gastric serosa on macroscopic evaluation underwent total gastrectomy, with extirpation of the spleen and pancreas tail.

The control group consisted of 18 patients, 4 of which were men $(22.2 \%)$ and 14 women (77.8\%). Mean age was $45.6 \pm 7.2$ years ( 35 to 57 years). All subjects presenting calculosis of the gallbladder and chronic cholecystitis confirmed by results in the anatomopathological exam report on the resected product, were submitted to preoperative high digestive endoscopy that revealed no gastric neoplasic disease, and then underwent laparotomy or laparoscopy. None of the patients in this group presented history of smoking. Levels of CEA and CA 19-9 in the peritoneal washing of these patients were determined, serving as normal controls.
The primary gastric carcinoma was located in the antropyloric region in 28 of our patients $(60.9 \%)$ and in the gastric body in $18(39.1 \%)$ subjects. Subtotal gastrectomy was performed in 26 $(56.5 \%)$ patients, total gastrectomy in $16(34.8 \%)$ and palliative gastrectomy in 4 patients $(8.7 \%)$.

Immediately following anesthetic induction, peripheral venous blood was collected through percutaneous punction of an upper limb vein and introduced into a vial without anticoagulant. The contents were then sent for analysis to determine sera levels of CEA and CA 19-9.

After completion of the operative procedure in patients with gastric neoplasias, and following removal of the biliary gallbladder in patients from the control group, $50 \mathrm{~mL}$ of physiologic solution heated to $37^{\circ} \mathrm{C}$ was introduced into the bottom of the Douglas sack. A portion of this liquid was aspirated and sent for analysis to determine levels of CEA and CA 19-9 in the peritoneal washing. A further portion was aspirated from the peritoneal washing and examined for neoplastic cells.

Levels of CEA and CA 19-9 in the sera and peritoneal washing were determined using electrochemiluminescent immunoassay. Normal pre-operative levels for sera CEA in patients with gastric carcinoma were $\leq 5.0 \mathrm{ng} / \mathrm{mL}$ and for sera CA $19-9$ were $\leq 33 \mathrm{U} / \mathrm{mL}$.

Preoperative levels of CEA and CA 19-9 in the sera and peritoneal washing were studied and compared with the diameter of gastric lesion across its widest point $(\leq 4 \mathrm{~cm} \text { and }>4 \mathrm{~cm})^{(30)}$, lymph node involvement, angiolymphatic invasion, depth of gastric wall invasion, and initial (stages I and II) or advanced staging (stages III and IV).

Statistical analysis employed the Chi-square test, multiple logistic regression, $t$-test, Mann-Whitney, Kruskall-Wallis, Spearman test, as well as the paired $t$-test, Wilcoxon and Tukey test. For quantitative variables, homogeneity of variances was verified by the Levene test, while normality was analyzed using the Kolmogorov-Smirnov test. A $0.05 \%$ or $5 \%$ level of significance was set for all tests.

\section{RESULTS}

The cytological study of peritoneal washing was negative for neoplastic cells in $39(84.8 \%)$ and positive in $7(15.2 \%)$ patients. There was no association between serum and peritoneal washing levels of CEA and CA 19-9 with the presence of tumoral cells in the cytological analysis of the peritoneal washing $(P=0.3)$.

Mean CEA level in peritoneal washings of cholecystectomized patients was $0.29 \pm 0.7 \mathrm{ng} / \mathrm{mL}(0.1$ to $3.1 \mathrm{ng} / \mathrm{mL})$ while mean CA $19-9$ was $4.53 \pm 2.8 \mathrm{U} / \mathrm{mL}$ (2.0 to $9.93 \mathrm{U} / \mathrm{mL}$ ).

In gastric carcinoma operated patients, the mean preoperative serum CEA level was $3.63 \mathrm{ng} / \mathrm{mL} \pm 5.21(0.2$ to $25.0 \mathrm{ng} / \mathrm{mL})$, while mean level in peritoneal washing was $4.6 \mathrm{ng} / \mathrm{mL} \pm 14.3$ ( 0.1 to $95.3 \mathrm{ng} / \mathrm{mL})$. A cut-off of $0.2 \mathrm{ng} / \mathrm{mL}$ was chosen, corresponding to combined high sensitivity (91\%) and specificity (72\%), according to the ROC curve (Receiver Operating Characteristics), a graphical representation of the level of true positive (sensitivity) versus false-positive levels (specificity) within a band of possible values for cut-off points. Mean preoperative 
TABLE 1. Comparison of CEA levels in the sera and peritoneal washing with anatomopathological aspects of gastric carcinoma

\begin{tabular}{lcc}
\hline & $\begin{array}{c}\text { Sera CEA } \\
\text { (ng/mL) }\end{array}$ & Peritoneal CEA (ng/mL) \\
\hline Lesion diameter $\$$ & $P=0.006^{*}$ & $P=0.347$ (NS) \\
$\leq 5 \mathrm{~cm}$ & $1.8 \pm 0.9$ & $2.5 \pm 4.5$ \\
$\mathrm{n}=16$ & $(0.4$ to 3.9$)$ & $(0.1$ to 17.5$)$ \\
$>5 \mathrm{~cm}$ & $3.0 \pm 3.7$ & $4.7 \pm 18.5$ \\
$\mathrm{n}=26$ & $(0.2$ to 14.4$)$ & $(0.1$ to 95.3$)$ \\
Stage§§ & $P=0.03^{*}$ & $P=0.16(\mathrm{NS})$ \\
Initial (I and II) & $1.9 \pm 1.9(0.2$ to 7.1$)$ & $1.8 \pm 2.4(0.2$ to 6.0$)$ \\
$\mathrm{n}=13$ & & \\
Advanced (III and IV) & $4.2 \pm 5.9(0.4$ to 25.0$)$ & $5.7 \pm 3.9(0.1$ to 95.3$)$ \\
$\mathrm{n}=33$ & & $P=0.02 *$ \\
Depth of invasion $(\mathrm{TNM}) \S$ & $P=0.001 *$ & $1.7 \pm 2.2$ \\
T1 & $1.4 \pm 1.3$ & $(0.2$ to 6.0$)$ \\
T2 & $(0.5$ to 3.9$)$ & $1.6 \pm 2.8$ \\
& $2.8 \pm 2.9$ & $(0.2$ to 5.8$)$ \\
T3 & $(0.4$ to 7.1$)$ & $4.5 \pm 16.8$ \\
& $2.7 \pm 3.2$ & $(0.1$ to 95.3$)$ \\
T4 & $(0.2$ to 14.4$)$ & $12.7 \pm 5.5$ \\
& $14.6 \pm 10.3$ & $(5.3$ to 12.7$)$ \\
\hline
\end{tabular}

$\mathrm{n}=$ number of patients ${ }^{*}=$ significant $\mathrm{NS}=$ not significant

$\S$ Wilcoxon signed ranks $\S \S$ Mann-Whitney test

sera CA 19-9 level was $17.5 \pm 24.8 \mathrm{U} / \mathrm{mL}(0.1$ to $101.3 \mathrm{U} / \mathrm{mL})$ and mean peritoneal washing level was $11.1 \pm 13.7 \mathrm{U} / \mathrm{mL}(0.1$ to $70.6 \mathrm{U} / \mathrm{mL}$ ). Values for CA $19-9$ levels in peritoneal washing were obtained in the same manner as for CEA, establishing a cut-off of $2.2 \mathrm{U} / \mathrm{mL}$, corresponding to combined high sensitivity $(69 \%)$ and specificity $(38.9 \%)$. Two patients disclosed the levels of CEA and CA 19-9 raised in serum, while one of them (stage IV) showed the level of the both tumor markers raised in the peritoneal washing also.

Mean gastric lesion size was $5.8 \pm 2.3 \mathrm{~cm}(0.6$ to $11.5 \mathrm{~cm})$. Sera CEA level correlated significantly with lesion diameter $(P=0.006)$, whereas CEA level in peritoneal washing showed no significant association $(P=0.347)$ (Table 1$)$. Those patients with gastric lesions $>5 \mathrm{~cm}$ in diameter demonstrated significantly higher sera CA $19-9$ values $(P=0.02)$ than patients having lesions $\leq 5 \mathrm{~cm}$. No significant association $(P=0.36)$ was observed between CA 19-9 levels in the peritoneal washing and lesion diameter (Table 2).

The mean number of lymph nodes extirpated from the 42 individuals who underwent operations was $31.9 \pm 10.4$ (10 to 54) lymph nodes. No significant difference $(P=0.19)$ was observed between sera CEA and peritoneal washing CEA levels for lymph node involvement by gastric carcinoma. Similarly, no significant difference was observed between sera CA 19-9 and peritoneal washing CA 19-9 levels in patients with lymph node involvement $(P=0.43)$. Comparison between patients with and without lymph node involvement by gastric carcinoma revealed significantly higher CA 19-9 levels in the peritoneal washing $(P=0.03)$ than in peripheral blood (Table 2). Comparison between patients with and without lymph node involvement by gastric carcinoma, showed no significant difference in the sera and peritoneal washing CEA levels ( $P=0.62$ and $P=0.13$, respectively).
TABLE 2. Comparison of CA 19-9 levels in the sera and peritoneal washing with anatomopathological aspects of gastric carcinoma

\begin{tabular}{|c|c|c|}
\hline & $\begin{array}{c}\text { Sera 19-9 } \\
(\mathrm{ng} / \mathrm{mL})\end{array}$ & $\begin{array}{c}\text { Peritoneal CA 19-9 } \\
(\mathrm{ng} / \mathrm{mL})\end{array}$ \\
\hline Lesion diameter§ & $P=0.02 *$ & $P=0.35(\mathrm{NS})$ \\
\hline$\leq 5 \mathrm{~cm} \mathrm{n}=16$ & $8.0 \pm 11.8(0.1$ to 47.0$)$ & $7.9 \pm 10.6(0.1$ to 38.4$)$ \\
\hline$>5 \mathrm{~cm} \mathrm{n}=26$ & $24.1 \pm 29.7(0.2$ to 101.3$)$ & $11.1 \pm 10.7(0.1$ to 35.9$)$ \\
\hline Lymph nodes§§ & $\mathrm{p}=0.43$ (N.S) & $\mathrm{p}=0.03^{*}$ \\
\hline $\begin{array}{l}\text { Compromised } \\
\mathrm{n}=30\end{array}$ & $19.7 \pm 25.0(0.1$ to 94.4$)$ & $14.1 \pm 15.6(0.3$ to 70.6$)$ \\
\hline $\begin{array}{l}\text { Free } \\
\mathrm{n}=16\end{array}$ & $13.4 \pm 24.6(0.2$ to 101.3$)$ & $5.4 \pm 6.6(0.1$ to 19.8$)$ \\
\hline Stage $\S$ & $P=0.54(\mathrm{NS})$ & $P=0.04^{*}$ \\
\hline $\begin{array}{l}\text { Initial (I and II) } \\
\mathrm{n}=13\end{array}$ & $13.9 \pm 26.7(0.2$ to 101.3$)$ & $5.0 \pm 6.5(0.1$ to 19.8$)$ \\
\hline $\begin{array}{l}\text { Advanced (III and IV) } \\
\mathrm{n}=33\end{array}$ & $18.9 \pm 24.2(0.4$ to 25.0$)$ & $13.4 \pm 3.9(0.2$ to 70.6$)$ \\
\hline
\end{tabular}

Eighteen (42.8\%) patients presented angiolymphatic invasion. No statistical difference was seen in the sera CEA levels $(P=0.51)$ and peritoneal washing CEA levels $(P=0.08)$ in relationship to the presence or absence of angiolymphatic invasion in gastric carcinoma patients, and likewise for CA 19-9 levels in sera $(P=0.20)$ and peritoneal washing $(P=0.26)$.

Depth of carcinoma invasion into the gastric wall was T1 in $6(13.0 \%)$ patients, T2 in $4(8.7 \%), \mathrm{T} 3$ in $32(69.5 \%)$ and $\mathrm{T} 4$ in 4 $(8.7 \%)$ cases. CEA levels in both peripheral blood and peritoneal washing showed significant association $(P=0.001$ and $P=0.02$, respectively) with the degree of carcinoma penetration into the gastric wall (Table 1), while CA 19-9 in the serum also showed significant association (0.05) with carcinoma penetration into the gastric wall, but not in the peritoneal washing $(P=0.27)$.

A total of 13 patients were found to be in the initial stage (stages I and II of the TNM classification) and $33(71.7 \%)$ patients were at advanced stages (stages III and IV of the TNM classification). Sera CEA levels presented a significant difference $(P=0.03)$ between initial and advanced stages, where this was not the case for CEA levels in the peritoneal washing $(P=0.16)$ (Table 1). Sera CA 19-9 levels showed no significant difference $(P=0.54)$ in relationship to initial or advanced gastric carcinoma stage, yet CA 19-9 levels in peritoneal washing were significantly $(P=0.04)$ greater in advanced than initial stages of gastric carcinoma (Table 2).

\section{DISCUSSION}

Gastric carcinoma patients with negative cytological tests for peritoneal washing can develop peritoneal metastases following curative surgery, illustrating the need to develop a more sensitive method for detecting potential sources of peritoneal recurrence ${ }^{(2,9,10,21)}$. Analyses of the cytology of peritoneal washing to identify neoplastic cells tend to present low rates of positivity ${ }^{(29)}$, observed in the present study which presented negative cytology of peritoneal washing for neoplastic cells in $39(84.8 \%)$ patients, proving positive in only $7(15.2 \%)$ patients. All patients with positive 
cytology for neoplastic cells in peritoneal washing presented more advanced stages of the disease.

Another issue to be elucidated is whether a finding of elevated peritoneal levels of markers necessarily implies the presence of neoplastic cells populating the peritoneal cavity. Given the fact that neoplastic cells can only be exfoliated from lesions invading the serosa of the organ, it can be assumed that exudative mechanisms exist which release tumor markers from the gastric mucous to the serosa and on to the peritoneal cavity ${ }^{(1,3,9)}$. Early gastric carcinoma may reveal increased tumoral marker in the peritoneal washing, suggesting the presence of penetration pathways in the stomach wall by tumoral cells, without invasion through continuation into the serosa ${ }^{(1,9)}$. Lymphatic channels or metastases in lymph nodes are examples of these possible pathways. This notion is partially supported by the fact that peritoneal recurrence takes place in around $1 \%$ of patients with early gastric carcinoma ${ }^{(19)}$.

Comparison of sera CEA and CA 19-9 levels with lesion size revealed a significant association between marker levels and neoplasia diameters greater than $4 \mathrm{~cm}$, where this constituted an independent risk for recurrence of gastric carcinoma in the multivariate analysis ${ }^{(4,30)}$. Since the source of marker production is the tumor itself, greater tumoral mass would hypothetically yield higher quantities of the marker. However, this may not be a linear relationship, since the presence of venous invasion as well as production capacity may contribute toward determining the level of tumoral marker entering circulation. The present study found no significant association between gastric lesion size and levels of CEA or CA 19-9 in the peritoneal washing.

In the current casuistic, CA 19-9 levels in the peritoneal washing of patients with involved lymph nodes by gastric carcinoma were significantly higher than in the peripheral blood, while also being significantly higher than in patients without lymph node involvement. These findings suggest that the level of CA 19-9 in the peritoneal washing is influenced by lymph node involvement by the gastric carcinoma and, if this is proven, determining this level may allow lymph node involvement to be ascertained even in the absence of evidence tumoral dissemination in imaging or anatomopathological exams. KODERA et al. ${ }^{(12)}$ also found a significantly greater number of lymph node metastases in patients with elevated sera CA19-9.

Results of the present study indicate increased CEA levels in both sera and peritoneal washing when lymph nodes are involved by carcinoma, although this did not reach significance. The protein produced by CEA can be absorbed by systemic circulation and raise sera CEA levels, followed by exudation from the systemic circulation into the peritoneal cavity, thereby increasing peritoneal CEA levels ${ }^{(1,9,25,30)}$. The raised sera CEA level could be the result of increased CEA production in the peritoneal cavity, which in turn, results in increases in peritoneal and sera CEA levels ${ }^{(25,30)}$. Sera CEA level was linked to the presence of positive peritoneal washing ${ }^{(1)}$. These results suggest that the lymph nodes infiltrated by the gastric carcinoma may not constitute significant CEA-producing tissue. GUADAGNI et al. ${ }^{(6)}$ also observed no link between lymph node involvement and sera CEA levels. However, significantly elevated levels of sera CEA in patients with metastases in lymph nodes have been documented ${ }^{(12,20,25)}$. KOGA et al. ${ }^{(13)}$ noted that as numbers of metastatic lymph nodes increased, sera CEA levels also rose significantly. These authors suggested that in patients with lymphatic metastases, tissue CEA is released into circulation through lymphatic vessels, diverting the tumor marker from the liver while increasing levels in the serum.

Results from the present casuistic revealed that the level of CA 19-9 in the peripheral blood showed no significant association with degree of carcinoma penetration into the gastric wall. TOMASICH et al. ${ }^{(26)}$, in a study involving 144 patients, assessed the association between sera CA 19-9 levels, depth of invasion into the gastric wall and staging of the gastric carcinoma. These authors concluded that the sera levels of CA 19-9 did not prove predictive for depth of invasion or for staging of neoplasia in patients with gastric carcinoma. Similarly, GUADAGNI et al.(6) found no association between serosa involvement and elevated sera CA 19-9 levels. However, KODERA et al. ${ }^{(12)}$ verified that neoplasias which extended beyond the muscle were more frequent in patients with elevated serum CA 19-9 levels. This finding was also observed in the present study where CEA levels in the peripheral blood and the peritoneal washing showed a significant association to the depth of carcinoma penetration into the gastric wall.

The present study showed that sera CA 19-9 levels in advanced neoplasias (stages III and IV) were not significantly higher than in less advanced stages (stages I and II). WOBBES et al. ${ }^{(28)}$ also found no association between stage of disease and positivity for CA19-9. This result could reflect that the determinants of CA 19-9 sera levels in gastric carcinoma may be related to morphological aspects of the neoplasias, which do not influence staging, such as size and degree of cellular differentiation of the neoplasias. JOYPAUL et al. ${ }^{(11)}$ found a difference between the mean value of sera CA 19-9 levels for initial and advanced tumors. Other authors have also shown that advanced stages of gastric carcinoma were more frequent in patients with high CA 19-9 levels in serum ${ }^{(18,24,27)}$. It appears that the CA 19-9 antigen from neoplastic cells is not released into the blood stream during initial stages of the carcinoma, but may enter circulation if lymphatic vessels or veins are invaded upon the spreading of the neoplasia ${ }^{(8,9,12,21)}$. This could explain the finding in the present work, although not significant, of more elevated sera CA 19-9 levels in more locally advanced gastric neoplastic lesions. On the other hand, levels of CA 19-9 in the peritoneal washing were significantly greater at advanced stages than the initial stage of the gastric carcinoma. This finding seems congruent with the probable determinant factors of CA 19-9 levels in the peritoneal cavity, factors which are commonly present in more advanced lesions, namely, greater penetration of the lesion into the gastric wall, lymph node metastases and the presence of neoplastic cells in the peritoneum ${ }^{(12,21,27)}$. Besides the presence of malignant cells in the peritoneal cavity, primary carcinoma or metastatic cells anywhere else in the body may also contribute toward increased peritoneal levels of CA 19-9. If these cells maintain the capacity to produce tumoral markers then the determination of levels of these substances may indicate the presence of such cells in the 
peritoneum and thus suggest the adoption of adjunct therapy to treat the microscopic disease $\mathrm{e}^{(1,3,9,10)}$.

$\mathrm{ABE}$ et al. ${ }^{(1)}$ analyzed the prognostic significance of CEA level in 54 patients with resected gastric carcinoma. The 5 -year survival rates were $97.1 \%$ with negative CEA in wash and $78.9 \%$ with positive CEA in wash. TACHIBANA et al. ${ }^{(25)}$ studied preoperative sera levels in 196 patients with gastric carcinoma submitted to surgical resection. Three and 5 year survival rates were $39.6 \%$ and $31.7 \%$, respectively in patients with elevated CEA, and $83 \%$ and $77.3 \%$ in those patients with normal sera CEA levels. IRINODA et al. ${ }^{(9)}$ observed that patients with gastric carcinoma and elevated levels of CEA in the peritoneal washing presented greater incidence of peritoneal metastases and lymph nodes. The prognosis of patients with high CEA levels in the peritoneal washing was significantly worse than those presenting normal levels. MANDORWSKI et al. ${ }^{(17)}$ studied CEA and CA 72-4 levels in the serum and peritoneal washings of 40 patients with gastric carcinoma. Eleven of these patients were classified as stage I or II, and 29 at stage III or IV. The blood and peritoneal washings were collected during the operation, prior to removal of the neoplasia. CEA levels in the peritoneal washing were higher in patients with tumors extending to the serosa or adjacent tissue (T3-T4) than those with tumors limited to the mucous or muscle layer (T1-T2) $(P=0.03)$. They also noted that CA 72-4 in the peritoneal washing was the sole marker able to differentiate the control group from the gastric carcinoma group.
Determinations of the levels of tumoral markers in the peritoneal washing disclose the potential of these being an indicator of occult peritoneal spread and contributing toward prognosis in patients with gastric carcinoma operated with curative intention $^{(1,9,10,13,22,29)}$. It is possible that, due to staging by the TNM classification grouping lesions exhibiting different degrees of parietal invasion and lymph node metastases into the same stage, the heterogeneity of anatomopathological aspects of the neoplasms may well contribute to the variability of results of tumoral marker determinations in the serum and peritoneal washing. These anatomopathological features may not influence disease prognosis, but may be significant in determining levels of the marker in the serum and peritoneal washings.

\section{CONCLUSIONS}

Elevated levels of CA 19-9 in the peritoneal washings were significantly associated with more advance stage of gastric carcinoma and proved a better predictive factor for staging than sera CA 19-9 levels. Sera CEA levels more accurately reflected neoplasia stage than levels in the peritoneal washing.

\section{ACKNOWLEDGEMENT}

The authors thanked Carlos Alberto Nagashima, Carmela Ambrico, Lourdes Conceição Martins and Vânia Lista for their technical support.

Crepaldi-Filho R, Palma RT, Giusti MF, Bueno MAG, Silva PSL, Waisberg J. Níveis do antígeno carcinoembriônico e do CA 19-9 no soro e no lavado peritonial em doentes submetidos ao tratamento cirúrgico do carcinoma gástrico. Arq Gastroenterol. 2008;45(3):219-24.

RESUMO - Racional - A recidiva peritonial precoce do carcinoma gástrico operado com intenção curativa continua sendo um grande desafio do seu tratamento e prevenção. Objetivo - Analisar a relação entre os níveis do marcador tumoral antígeno carcinoembriônico (CEA) e CA 19-9 no sangue e no lavado peritonial e os aspectos anatomopatológicos do carcinoma gástrico. Método - Dos 46 doentes do estudo, 29 (63,0\%) eram do sexo masculino e 17 (37,0\%) do feminino. A média de idade foi de 63,6 $\pm 11,7$ anos (31 a 91 anos). Após a indução anestésica, o sangue venoso periférico foi coletado de veia do membro superior para a determinação do nível sérico do CEA e CA 19-9. Após o término do procedimento operatório foram derramados $50 \mathrm{~mL}$ de solução fisiológica no fundo de saco de Douglas, aspirada alíquota que foi encaminhada para a determinação do nível no lavado peritonial do CEA e CA 19-9. O nível do CEA e do CA 19-9 sérico e no lavado peritonial foram relacionados às seguintes variáveis: diâmetro da lesão $\leq 4 \mathrm{~cm}$ ou $>4 \mathrm{~cm}$, comprometimento linfonodal, invasão angiolifática, profundidade de invasão na parede gástrica e estádio inicial ou tardio. Resultados - Em relação ao CEA, o nível sérico foi significantemente maior nos doentes com o diâmetro da lesão $>5 \mathrm{~cm}$. O nível de CEA sérico e no lavado peritonial foi significantemente maior nos doentes com carcinoma gástrico com células em anel de sinete. O nível de CEA no sangue periférico e no lavado peritonial mostrou relação significante com o nível de penetração do carcinoma na parede gástrica, e o CEA sérico foi significantemente mais elevado nos doentes com estádio mais avançados. Não houve diferença significante entre os valores do CEA sérico e peritonial nos carcinomas mais diferenciados em relação aos menos diferenciados. No tocante ao CA 19-9, os enfermos com lesões gástricas com diâmetro $>5 \mathrm{~cm}$ e mais diferenciadas exibiram valores séricos de CA 19-9 significantemente maiores. Nos doentes com linfonodos comprometidos pelo carcinoma gástrico, os níveis de CA 19-9 no lavado peritonial foram significantemente maiores do que os no sangue periférico. Níveis do CA 19-9 no lavado peritonial foram significantemente maiores no estádio avançado em relação ao estádio inicial do carcinoma gástrico. Conclusões Níveis elevados do CA 19-9 no lavado peritonial foi significantemente associado com estádios mais avançados do carcinoma gástrico e foi fator preditivo mais fidedigno para o estádio do que os níveis séricos do CA 19-9. Os níveis séricos do CEA refletiram mais acuradamente o estádio da neoplasia do que os níveis no lavado peritonial.

DESCRITORES - Antígeno carcinoembrionário. Antígeno CA-19-9. Lavagem peritonial. Neoplasias gástricas. Carcinoma. 


\section{REFERENCES}

1. Abe S, Yoshimura H, Tabara H, Tachibana M, Monden N, Nakamura T, Nagaoka S Curative resection of gastric cancer: limitation of peritoneal lavage cytology predicting the outcome. J Surg Oncol. 1995;59:226-9.

2. Baba H, Korenaga D, Okamura T, Saito A, Sugimachi K. Prognostic factors in gastric cancer with serosal invasion. Univariate and multivariate analyses. Arch Surg. 1989;124:1061-4

3. Benevolo M, Mottolese M, Cosimelli M, Tedesco M, Giannarelli D, Vasselli S, Carlini M, Garofalo A, Natali PG. Diagnostic and prognostic value of peritoneal immunocytology in gastric cancer. J Clin Oncol. 1998;16:3406-11

4. Fletcher RH. Carcinoembryonic antigen. Ann Intern Med. 1986;104:66-73.

5. Gold P, Freedman SO. Demonstration of tumor-specific antigens in human colonic carcinomata by immunological tolerance and absorption techniques. J Exp Med. 1965;121:439-62.

6. Guadagni S, Catarci M, Kinoshita T, Valenti M, De Benardinis G, Carboni M Causes of death and recurrence after surgery for early gastric cancer. World J Surg. 1997;21:434-9.

7. Gupta MK, Arciaga R, Bocci L, Tubbs R, Raymond T, Bukowski R, Deodhar SD Measurement of a monoclonal-antibody-defined antigen (CA 19-9) in the sera of patients with malignant and nonmalignant diseases. Comparison with carcinoembryonic antigen. Cancer. 1985;56:277-83.

8. Haglund C, Roberts PJ, Jalanko H, Kuusela P. Tumor markers CA 19-9 and CA 50 in digestive tract malignancies. Scand J Gastroenterol. 1992;27:169-74.

9. Irinoda T, Terashima M, Takagane A, Sasaki N, Abe K, Araya M, Nishizuka S, Yonezawa H, Nakaya T, Shimooki O, Oyama K, Ikeda K, Saito K. Carcinoembryonic antigen level in peritoneal washing is a prognostic factor in patients with gastric cancer. Oncol Rep. 1998;5:661-6.

10. Ito S, Nakanishi H, Kodera Y, Mochizuki Y, Tatematsu M, Yamamura Y. Prospective validation of quantitative CEA mRNA detection in peritoneal washes in gastric carcinoma patients. Br J Cancer. 2005;93:986-92.

11. Joypaul B, Browning M, Newman E, Byrne D, Cuschieri A. Comparison of serum CA 72-4 and CA 19-9 levels in gastric cancer patients and correlation with recurrence. Am J Surg. 1995;169:595-9.

12. Kodera Y, Yamamura Y, Torii A, Uesaka K, Hirai T, Yasui K, Morimoto T, Kato T, Kito T. The prognostic value of preoperative serum levels of CEA and CA 19-9 in patients with gastric cancer. Am J Gastroenterol. 1996;91:49-53.

13. Koga T, Kano T, Souda K, Oka N, Inokuchi K. The clinical usefulness of preoperative CEA determination in gastric cancer. Jpn J Surg. 1987;17:342-7.

14. Lourenço LG, Hamada GS. Gastric cancer in Brazil. Gastric cancer. 2001;4:103-5.

15. Maehara Y, Hasuda S, Koga T, Tokunaga E, Kakeji Y, Sugimachi K. Postoperative outcome and sites of recurrence in patients following curative resection of gastric cancer. Br J Surg. 2000;87:353-7.

16. Magnani JL, Steplewski Z, Koprowski H, Ginsburg V. Identification of the gastrointestina and pancreatic cancer-associated antigen detected by monoclonal antibody $19-9$ in the sera of patients as a mucin. Cancer Res. 1983;43:5489-92.
17. Mandorwski S, Lourenço LG, Forones NM. CA 72-4 e CEA no soro e no lavado peritoneal de doentes com câncer gástrico. Arq Gastroenterol. 2002;39:17-21.

18. Mattar R, Andrade CRA, Mastrantonio F, Gama-Rodrigues JJ, Laudanna AA. Preoperative serum levels of CA 72-4, CEA, CA 19-9, and alpha-fetoprotein in patients with gastric cancer. Rev Hosp Clin Fac Med S Paulo. 2002;57:89-92.

19. Nakamura K, Ueyama T, Yao T, Xuan ZX, Ambe K, Adachi Y, Yakeishi Y, Matsukuma A, Enjoji M. Pathology and prognosis of gastric carcinoma; findings in 10.000 patients who underwent primary gastrectomy. Cancer. 1992;70:1030-7.

20. Nakane Y, Okamura S, Akehira K, Boku T, Okusa T, Tanaka K, Hioki K. Correlation of preoperative carcinoembryonic antigen levels and prognosis of gastric cancer patients. Cancer. 1994;73:2703-8

21. Pectasides D, Mylonakis A, Kostopoulou M, Papadopoulou M, Triantafillis D, Varthaliti J, Dimitriades M, Athanassiou A. CEA, CA 19-9, and CA-50 in monitoring gastric carcinoma. Am J Clin Oncol. 1997;20:348-53.

22. Ribeiro U Jr, Safatle-Ribeiro AV, Zilberstein B, Mucerino D, Yagi OK, Brescian CC, Jacob C, Iryia K, Gama-Rodrigues J. Does the intraoperative peritoneal lavage cytology add prognostic information in patients with potentially curative gastric resection? J Gastrointest Surg. 2006;10:170-7.

23. Sano T, Sasako M, Kinoshita T, Maruyama K. Recurrence of early gastric cancer. Followup of 1475 patients and review of the Japanese literature. Cancer. 1993;72:3174-8.

24. Souza Jr OG, Souza EMN, Feio FMS. Correlação da dosagem sérica do CA 19-9 em pacientes com adenocarcinoma gástrico. Rev Para Med. 1999;13:29-33.

25. Tachibana M, Takemoto Y, Nakashima Y, Kinugasa S, Kotoh T, Dhar DK, Kolmo H, Nagasue N. Serum carcinoembryonic antigen as a prognostic factor in resectable gastric cancer. J Am Coll Surg. 1998;187:64-8.

26. Tomasich FDS, Augusto VC, Luz MA, Dias LAN, Kato M. Correlação entre os marcadores tumorais CEA e CA 19-9 e a profundidade de invasão no câncer gástrico. Rev Bras Cancerol. 2002;48:57-62.

27. Victorzon M, Haglund C, Lundin J, Roberts PJ. A prognostic value of CA 19-9 but not of CEA in patients with gastric cancer. Eur J Surg Oncol. 1995;21: 379-84.

28. Wobbes T, Thomas CMG, Segers MFG, Nagengast FM. Evaluation of seven tumor markers (CA 50, CA 19-9 TruQuant, CA 19-9, CA 195, carcinoembryonic antigen, and tissue polypeptide antigen) in the pretreatment sera of patients with gastric carcinoma. Cancer. 1992;69:2036-41.

29. Yamamoto M, Baba H, Kakeji Y, Endo K, Ikeda Y, Toh Y, Kohnoe S, Okamura T, Maeharo Y. Prognostic significance of tumor markers in peritoneal lavage in advanced gastric cancer. Oncology. 2004;67:19-26.

30. Yoo CH, Noh SH, Shin DW, Choi SH, Min JS. Recurrence following curative resection for gastric carcinoma. Br J Surg. 2000;87:236-42. 